The study was conducted during the monsoon season of July 2012 and was confirmed again during the two subsequent monsoons of 2013 and 2014. The authors have been recording the floristic diversity OPEN ACCESS

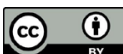
of important sites like Anjaneri, Borgad, Kalsubai (north face) and Trimbakeshwar around the district, including the location of this record.

Map of the occurrence site has been attached (Image 1).

Taxonomic identity was confirmed with the help of Dr. Sanjay Rahangdale, Dr. Savita Rahangdale, and Dr. Mandar Datar. The newly recorded species is a highly threatened plant and has legal limitations for collection and herbarium making. A series of geo-tagged, digital imageries of the species at its new location of Ramshej Fort have therefore been recorded for accuracy and locations. These imageries have been forwarded to the local forest department for appropriate conservation action.

Results: Ceropegia mahabalei Hemadri \& Ansari is tuberous herb with long linear leaves (Image 2a,b). It is found growing on grassy slopes of hills. It has been reported as critically endangered and endemic to Maharashtra (non IUCN Red List: Mishra \& Singh 2001; Yadav \& Kamble 2008). We observed the plant to be growing in association with herbaceous species Commelina benghalensis Linn., Impatiens balsamina Linn., Justicia sp., in a small population of not more than 25 individuals.

A detailed description of the recorded species is given: Ceropegia mahabalei Hemadri \& Ansari, locally known as "Gavati Kharpudi", herbaceous, erect and

\section{ADDITIONAL RECORDS OF THE HIGHLY threatened CEROPEgIa MAHABALEI HeMAdRI \& ANSARI (ASCLEPIADOIDEAE: APOCYNACEAE) FROM NASHIK DISTRICT, MAHARASHTRA, INDIA}

\author{
Jui Pethe ${ }^{1} \&$ Amit Tillu ${ }^{2}$
}

\begin{abstract}
${ }^{1}$ Principal Investigator, Wild Edible Plants Study Project, Nature Conservation Society of Nashik, Shripad, Vakratund R.H., Opp. Rama Raman Apt., Vrindavan Nagar, Kamatwade, Nashik, Maharashtra 422010, India

${ }^{2}$ Shripad, 1, Vakratund R.H., Vrindavan Nagar, Kamatwade, Nashik, Maharashtra 422010, India 1.juipethe@gmail.com (corresponding author), ªmittillu@gmail.com
\end{abstract}

20-65 cm in height. Its flowers are beautiful, attractive, single; pedicles and calyx hairy; corolla $5.5-10.0 \mathrm{~cm}$ long, base largely inflated, narrowed in neck, enlarging towards mouth, glabrous inside, lobes hairy within, connate at tips to form a beaked crown; corona biseriate, outer corona of five bidentate glabrous lobes, inner linear, erect. Fruit is pair of follicles, terete, glabrous, linear and tapering at the end. Flowering in AugustSeptember and fruiting September onwards (Almeida 2001; Singh et al. 2001).

Discussion: Mishra \& Singh (2001) reported the species in Junnar in Pune, Satara, and Kalsubai Peak in Ahmednagar District of Maharashtra. Malpure et al. (2006) mention its occurrence in Pune, Satara, and Kasara in Thane District. This record of species from Ramshej Fort, Nashik District at geolocation $20^{\circ} 6^{\prime} 20.51^{\prime \prime} \mathrm{N} \& 73^{\circ} 46^{\prime} 7.44^{\prime \prime}$, elevation $311 \mathrm{~m}$ is not only a new report for the district but also the eastern most distribution record of this species. Local naturalists also report having observed the plant from the adjoining

DOI: http://dx.doi.org/10.11609/jott.2821.8.5.8844-8845

Editor: M.K. Vasudeva Rao, Shiv Ranjani Housing Society, Pune, India.

Date of publication: 26 May 2016 (online \& print)

Manuscript details: Ms \# 04101 | Received 08 October 2015 | Final received 28 April 2016 | Finally accepted 02 May 2016

Citation: Pethe, J. \& A. Tillu (2016). Additional records of the highly threatened Ceropegia mahabalei Hemadri \& Ansari (Asclepiadoideae: Apocynaceae) from Nashik District, Maharashtra, India. Journal of Threatened Taxa 8(5): 8844-8845; http://dx.doi.org/10.11609/jott.2821.8.5.8844-8845

Copyright: (C) Pethe \& Tillu 2016. Creative Commons Attribution 4.0 International License. JoTT allows unrestricted use of this article in any medium, reproduction and distribution by providing adequate credit to the authors and the source of publication.

Funding: None.

Conflict of Interest: The authors declare no competing interests

Acknowledgement: The authors are thankful to Drs. Mr. \& Mrs. Rahangdale, Dr. Mandar Datar for the taxonomic confirmation of the species and Mr. Arvind Patil, Chief Conservator of Forests (Territorial), Nashik Circle, for his continuous support in field activities. 


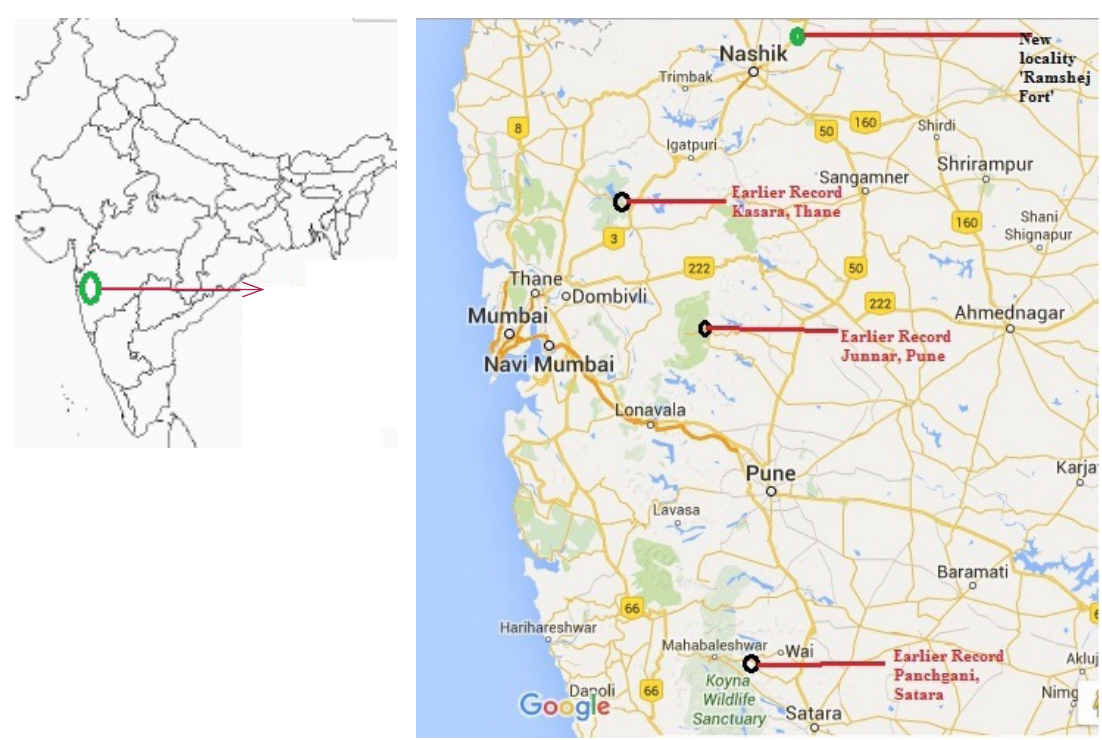

Image 1. Map of newly recorded location of Ceropegia mahabalei Hemadri \& Ansari
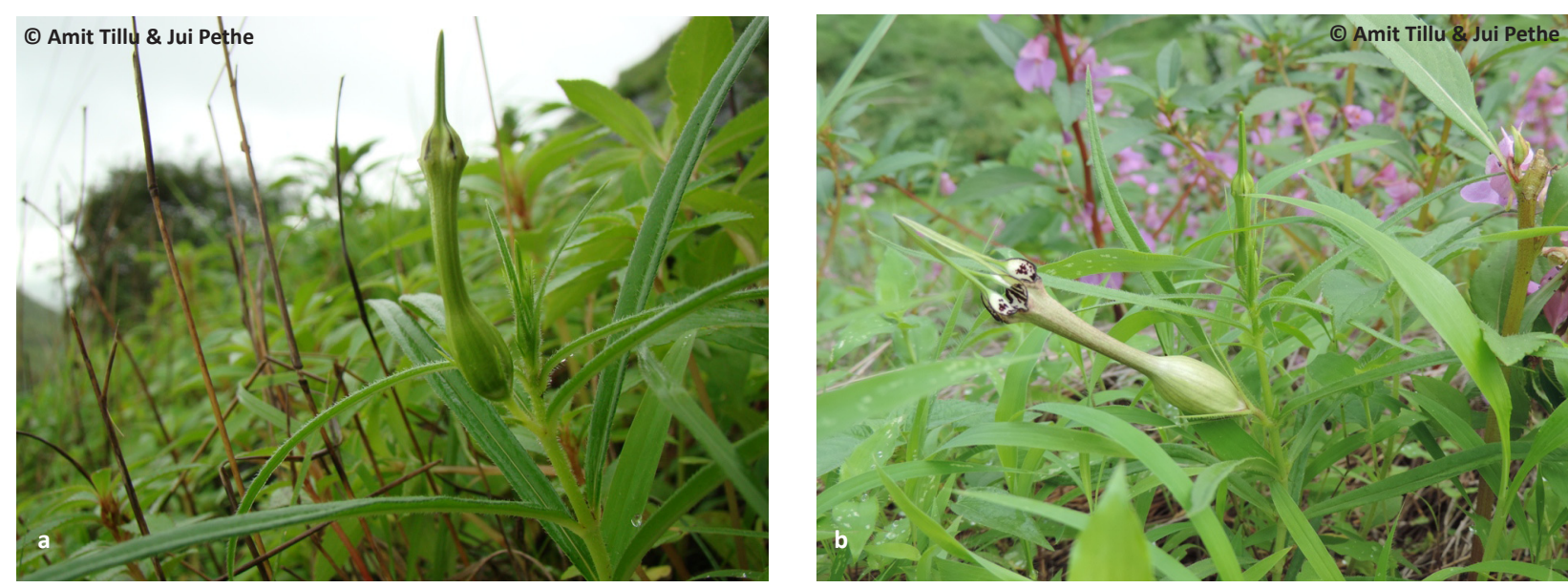

Image 2. Ceropegia mahabalei blooming in its habitat.

Borgad Conservation Reserve. The small population of not more than 25 individuals is threatened by grazing, trampling, tourism and extraction.

\section{References}

Almeida, M.R. (2001). Flora of Maharashtra - Vol. 3a. Orient press, Mumbai, 300pp.

Hemadri, K., \& M.Y. Ansari (1971). Ceropegia mahabalei Hemadri \& Ansari - a new species of Ascelpiadaceae from Sahyadri Range, Western Ghats (Maharashtra State). Indian Forester 97(2): 105-108. Malpure N., M. Kamble \& S.R. Yadav (2006). A new species of Ceropegia L. (Asclepiadaceae) from the Western Ghats of India with a note on series Attenuatae Huber. Current Science 91(9): 11401142.
Mishra, D.K. \& N.P. Singh (2001). Endemic and Threatened Flowering Plants of Maharashtra. Botanical Survey of India, Calcutta, 126$128 p$.

Nayar, M.P. \& A.R.K. Sastry (eds.) (1988). Red Data Book of Indian Plants - Vol. II. Botanical Survey of India, Calcutta, 268pp.

Singh, N.P., P. Lakshminarasimhan, S. Karthikeyan \& P.V. Prasanna (2001). Flora of Maharashtra State (Combretaceae to Ceratophyllaceae) - Vol. II. Botanical Survey of India, Calcutta, 1080pp.

Yadav, S.R. \& M.Y. Kamble (2008). Threatened Ceropegias of the Western Ghats and strategies of their Conservation, Special Habitats and Threatened Plants of India. ENVIS Bulletin: Wildlife and Protected Areas 11(1): 146-157. 